\title{
THE ERROR ANALYSIS REFLECTED IN ENGLISH RECOUNT WRITING
}

\author{
N. W. Y. Megantari ${ }^{1}$, I. G. Budasi ${ }^{1}$ \\ ${ }^{1}$ Universitas Pendidikan Ganesha \\ e-mail: yunitamegantari@yahoo.co.id, gede.budasi@undiksha.ac.id
}

\begin{abstract}
This study was designed in the form of descriptive qualitative that describe the Analysis of Errors Reflected in Recount Writing Committed by the Tenth Grade Students of SMK Negeri 1 Denpasar. This study aimed at identifying and describing the types and sources of errors. The subjects of this study were the tenth grade students of SMK Negeri 1 Denpasar. The participants of this study were 28 students of class X RPL 1.The data were collected based on the students' recount writings. There were two techniques to collect the data, namely guided writing and free writing. The errors were classified into 13 types of error as suggested by (Azar, 1999) and (Zawahreh, 2012) namely: singular/plural, word form, verb tense, add a word, omit a word, word order, spelling, punctuation, capitalization, meaning not clear, run-on sentence, preposition, and pronoun. The results of the analysis show there were 307 errors found in Holiday Task 1, 328 errors found in Holiday Task 2, 183 errors were found in Unforgettable Experience Task 1, and 264 errors were found in Unforgettable Experience Task 2. The sources of errors were classified into three types based on the result of student's writing as suggested by (Richards, 1971) and Brown (1980) namely: Intralingual, Interlingual, and Communication Strategy. The most frequent sources of errors were caused by communication strategy with 587 errors (63\%), intralingual with 336 errors $(36,51 \%)$, and interlingual with 4 errors $(0,42 \%)$.
\end{abstract}

Keywords: error analysis, types of error, sources of error

\section{INTRODUCTION}

Writing skill is one of the skills that should be mastered by English as a foreign language students. While doing a teacher training program conducted from 12th February until $7^{\text {th }}$ April 2018 the researcher found that most students had difficulty in writing, especially when writing recount texts. Writing recount text is one of the texts taught by teachers in the school. In writing recount text, students are expected to be able to develop a type of recount genre of text. Recount text is a type of texts that tell about events in the past. The most important thing that should be highlighted in the form of writing is ideas. Harmer (2004) states that writing is a process of transferring the idea in written form. To be able to tell an event or experience, students need to express their ideas in writing. Based on interviews conducted on $26^{\text {th }}$ until $28^{\text {th }}$ February 2018 more than $80 \%$ of students of SMK N 1 Denpasar considered writing is very difficult because they have to put ideas together into a good paragraph.
Based on the interviews, the difficulty in writing is caused by having no idea, having fear of making mistakes, having a lack of vocabulary, and having low grammar or tense mastery.

The researcher gave some writing exercises to gain some pre-data on recount text on Friday, $2^{\text {nd }}$ March 2018. From the writing collected during the exercise, it was found that the students made some errors. While studying in the class, the students often made errors in the use of grammar. Errors happened when the students transfer Indonesian sentences into English like the sentence found in one of students writing saya lelah setelah sampai dirumah in Indonesian form was translated into 'I tired after arrived at home. In that case, the student made an error. Supposedly the correct structure in English should be I was tired when I arrived home'. Thus, it is assumed that the error might occur when the student still transfers Bahasa Indonesia's sentence structure into the English sentence. Besides, it can be said that the use of English sentence by students was influenced by the 
structure of the first language in this case by the Indonesian sentence structure.

Researches on the interference of the first language on foreign language performance have been conducted by (Hartati, 2017) states that in her research about the error of effective sentences in student scientific articles. She found that the errors in the effective use of the sentences contained in the student's scientific articles are inherent in the element of unity, coherence, precision, austerity, and reasoning or logic. So, it can make the sentence to be ineffective. Another researcher conducted research on the influence of the first language on the interlanguage (Noviani, 2015) conducted a study about an error analysis on student's recount writing. She found that the students commonly made an error caused by intralingual transfer. They mostly made an error in verb tense, add a word, omitting a word, and singular plural. Moreover, in general learners' have difficulty in learning the target language. They tend to bring the first language rules into the target language which influenced the rules of the target language.

In this study, grammar will be the focus of the research. Most of the students experience grammar errors in the form of interlanguage. Interlanguage is a language learned between the mother tongue and the target language. Selinker (1972) states that interlanguage is a language that stands between the mother tongue and the target language being studied. Therefore, interlanguage has its own grammar and characteristic (Corder, 1977). Therefore, errors made by students occur naturally. Ellis (1997) explains the learners often make errors in both comprehension and production in the target language. It happened because they still think that the sentence structure of the first language and the target language is the same.

Therefore, grammar is an important thing to know by students. Based on the observation, the students often make errors when they write something. It is due to English grammar is different from Indonesian grammar. Noviyanti (2013) states that first language acquisition (L1) student difficult to develop their English proficiency. It happened because of interlanguage. Noviyanti also found the common problem usually face in writing, students tend to translate their idea in Bahasa Indonesia into English without caring about grammar. Therefore, the difference between first language and second language grammar become the factor which influences students to make an error while writing. Then, the content of the message is not clearly communicated. Brown (1980) states that the learner's errors occur in the target language because of the learner's assumption that the target language has almost the same structure as the first language or native language. That is why students do not know how to perform the correct sentences in writing. They are confused by the differences in grammar structure. In order to avoid errors in writing, error analysis can be used to determine the correct and the wrong structure. Richards (1971) states that error can occur due to the differences between the way how people learn a language and the way how native speakers use the language. It means that errors can occur depending on the people itself. The following is an example of grammatical errors affected by the interlanguage made by students in writing recount text.

Furthermore, the researcher was interested in conducting a study about errors found in writing recount text by students who learn English as a target language. The researcher chose to analyze errors in writing recount text based on the experience when the writer was in a teacher training program at the senior high school level. It turned out that the student had many errors while writing recount text. Based on the phenomenon itself, this study, concerning the students' error in writing recount text, is very important because grammar is the basic skill for learning English. Learning grammar is very important for students in order to answer the tests during an examination. As it is considered important to conduct a research regarding students' error in writing, the researcher constructs the title of this study that is "The Analysis of Error Reflected in The Recount Writing Committed by the Tenth Grade Student of SMK Negeri 1 Denpasar".

\section{RESEARCH METHOD}

This study is designed in a descriptive qualitative study. The subjects of this study were the $10^{\text {th }}$ grade students of SMK N 1 Denpasar. They have been learning English for 7 years since 
elementary school until senior high school. The participants of this study were 28 students of class X RPL 1 . There were 16 males and 12 females. They were chosen because the researcher taught them and observed some grammatical errors made by the students when the researcher as a teacher training at SMK N 1 Denpasar. The objects of this study were the types and the sources of errors in writing recount texts committed by the student of SMK N 1 Denpasar. The researcher used writing tests as the instruments for collecting the data. The researcher asked the students to write four recount texts about the topic given. It was taken to find out what types and sources of grammatical errors were committed by the $10^{\text {th }}$ grade students of SMK N 1 Denpasar. The data was analyzed descriptively.

The steps of analysis are as follows. First, Identifying the Errors: To identify an error in students' writing the researcher identified and marked by red color in their recount text. Second, Classifying the Types of Errors: The errors were classified to several types of errors based on theories which are the combination of (Azar, 1999) and (Zawahreh, 2012) theories. There are 13 types of errors namely; singular/plural, word form, verb tense, add a word (+), omit a word (-), word order, spelling, punctuation, capitalization, meaning not clear, run-on sentence, preposition, and pronoun. The error were classified and drawing in tables. Third, counting the errors: After all of the errors were classified into their types, it was concluded and calculated to know the total number and the percentage of the errors committed by the students in each type. The researcher used the following formula in counting the percentage:

$$
p=\frac{n 1}{\sum n} \times 100 \%
$$

\section{Adopted from Haryanto (2007, p.26)}

In which,

P : Percentage of each error

$\mathrm{n} 1$ : total of the given error

$\Sigma$ : total of the whole error

By calculating the frequency of error, the researcher identified the most common error committed by the students. Fourth, Analyzing the
Sources of Errors: In analyzing the source of error, the researcher did an analysis based on the result of students' writings in recount text. The researcher analyzed them using Richard's and Brown's theories of the sources of errors namely; interference error, intralingual error, the context of learning, and communication strategy. Last, Reporting the Result of the Analysis: After obtaining or finding various data, the researcher reported and presented the result of the study descriptively using graphics, tables, and narrate the findings.

\section{FINDINGS AND DISCUSSION}

\section{The Frequency of Errors Made by Students}

This study was conducted to find out and analyze the error analysis reflected in recount writings committed by the $10^{\text {th }}$ grade student of SMK Negeri 1 Denpasar. There were 28 students in the class. As what have already been mentioned, the data of this study were obtained through collecting students' recount writing texts. The researcher gave two techniques in conducted the students' writings: guided writing and free writing. Both contained the same topic. The researcher gave two themes. On each theme, the students were asked to write recount texts namely guided writing and free writing. In guided writing, the researcher provided some printout pictures. Then, the students had to write based on the pictures. In the free writing task, the students had to write their own experience based on the topic given without any pictures as guides. After that, the students' writings were collected and analyzed as the data and findings of this study. After conducting the tests, the researcher analyzed and marked the errors and sources of errors in some colors. The colors showed which sentences were considered errors based on the categories mentioned.

To make it easier, the researcher drew up a table of errors' identification. There were 28 students, each of them was coded S1 (student 1) to S28 (student 28). Furthermore, in classifying the data, each sentence was coded: HD T1 = Holiday Task1, HD T2 = Holiday Task2, UNE T1 = Unforgettable Experience Task1, UNE T2 = Unforgettable Experience Task2, S1 ST1 = Student1 Sentence1, S1 ST2 = Student1 Sentence2, S2 ST1 = Lingua Scientia | 39 
Student2 Sentence1, S2 ST2 = Student2 Sentence2, etc. The types of errors identified in this study were adapted from (Azar, 1999) and (Zawahreh, 2012). The total numbers of errors found were 13 types as described in the following list. Singular/plural, word form, verb tense, add a word, omit a word, word order, spelling, punctuation, capitalization, meaning not clear, run-on sentence, preposition, pronoun. The result of the analysis shows that there are 307 errors found in HD T1, 328 errors in HD T2, 183 errors in UNE T1, and 264 errors in UNE T2. As shown in Figure 1



Figure 1. Number of the Types of Students' Errors

Based on Figure 1, the codes of the errors are singular/plural $(S / P)$, word form (WF), verb tense (VT), add a word (AW), omit a word (OW), word order (WO), spelling (SPL), punctuation (PT), capitalization (CZ), meaning not clear (MC), run-on sentence (RS), preposition (Prep), and pronoun (PN). From the chart, it can be seen that the most frequent errors were capitalization (CZ) on HD T2 with 78 errors or $23,70 \%$, punctuation (PT) on HD T1 73 errors or $23,11 \%$, run-on sentence (RS) on HD T2 with 65 errors or $19,75 \%$, verb tense (VT) on UNE T2 with 59 errors or $22,18 \%$, and punctuation
(PT) on HD T2 with 55 errors or $16,71 \%$. It can be concluded that, there are five types of errors showed as the most frequent error made by the students.

The researcher analyzed the data based on the need of the data analysis as stated in the procedures of data analysis. The aim was to find out the common errors committed by the students in their writing texts. By using the formula of percentage, the types of errors, the number of errors, and the percentages of errors are presented in Table 1.

Table 1. Percentage of the Types of Student's Errors in Task 1 with the Topic "Holiday"

\begin{tabular}{ccccl}
\hline No. & Types of Error & $\begin{array}{c}\text { The Number of } \\
\text { Error }\end{array}$ & $\begin{array}{c}\text { Percentage of } \\
\text { Error }\end{array}$ & Task Code \\
\hline 1. & Punctuation & 73 & $23,77 \%$ & \\
2. & Capitalization & 51 & $16,61 \%$ & \\
3. & run-on sentence & 45 & $14,65 \%$ & \\
4. & verb tense & 37 & $12,05 \%$ & \\
5. & pronoun & 25 & $8,14 \%$ & \\
6. & spelling & 18 & $5,86 \%$ & HD T1 \\
7. & omit a word (-) & 15 & $4,88 \%$ & \\
8. & preposition & 11 & $3,58 \%$ & \\
9. & singular/plural & 8 & $2,60 \%$ & \\
10. & add a word (+) & 7 & $2,28 \%$ & \\
11. & meaning not clear & 7 & $2,28 \%$ & \\
\end{tabular}






From the 13 types of errors committed by the students which can be seen in Table 4.1., punctuation is the most frequent error made by the $10^{\text {th }}$ grade students of SMK N 1 Denpasar (committed 73 errors of 305 errors or $23,77 \%$ ). It is then followed by capitalization with 51 errors or $16,61 \%$, run-on sentence with 45 errors, verb errors with 37 errors or $12,05 \%$, pronoun with 25 errors or $8,14 \%$, spelling with 18 errors or $5,86 \%$, omitting word with 15 errors or $4,88 \%$, preposition with 11 errors or $3,58 \%$, singular/plural with 8 errors or $2,60 \%$, add a word and not clear meaning have the same number with 7 errors or $2,28 \%$, and word order with 3 errors or $0,97 \%$.

Table 2. Percentage of the Types of Student's Errors in Task 2 with the Topic "Holiday"

\begin{tabular}{ccccc}
\hline No. & Types of Error & $\begin{array}{c}\text { The Number of } \\
\text { Error }\end{array}$ & $\begin{array}{c}\text { Percentage of } \\
\text { Error }\end{array}$ & Task Code \\
\hline 1. & capitalization & 78 & $23,70 \%$ & \\
2. & run-on sentence & 65 & $19,75 \%$ & \\
3. & punctuation & 55 & $16,71 \%$ & \\
4. & verb tense & 39 & $11,85 \%$ & \\
5. & add a word (+) & 18 & $5,47 \%$ & \\
6. & pronoun & 18 & $5,47 \%$ & HD T2 \\
7. & singular/plural & 16 & $4,86 \%$ & \\
8. & spelling & 15 & $4,55 \%$ & \\
9. & omit a word (-) & 11 & $3,34 \%$ & \\
10. & meaning not clear & 6 & $1,82 \%$ & \\
11. & preposition & 3 & $0,91 \%$ & \\
12. & word form & 2 & $0,60 \%$ & \\
13. & word order & 2 & $0,60 \%$ & \\
\hline
\end{tabular}

In Table 2 we can see that from 13 types of error committed by the students, capitalization is the most frequent error in the $10^{\text {th }}$ grade students of SMK N 1 Denpasar. They committed 78 errors of 328 errors or $23,70 \%$. It is then followed by run-on sentence 65 errors or $19,75 \%$, punctuation 55 errors or $16,71 \%$, verb error 39 errors or $11,85 \%$, add a word and pronoun have the same number with 18 errors or $5,47 \%$, singular/plural with 16 errors or $4,86 \%$, spelling with 15 errors or $4,55 \%$, omitting word with 11 errors or 3,34\%, not clear meaning with 6 errors or $1,82 \%$, preposition with 3 errors or $0,91 \%$, and the last are word form and word order with 2 errors or $0,60 \%$.

Table 3. Percentage of the Types of Student's Errors in Task 1 with the Topic "Unforgettable Experience"

\begin{tabular}{ccccc}
\hline No. & Types of Error & $\begin{array}{c}\text { The Number of } \\
\text { Error }\end{array}$ & $\begin{array}{c}\text { Percentage of } \\
\text { Error }\end{array}$ & Task Code \\
\hline 1. & run-on sentence & 48 & $26,22 \%$ & \\
2. & verb tense & 47 & $25,68 \%$ & \\
3. & punctuation & 37 & $20,21 \%$ & \\
4. & capitalization & 22 & $12,02 \%$ & \\
5. & spelling & 8 & $4,37 \%$ & UNE T1 \\
6. & singular/plural & 6 & $3,27 \%$ & \\
7. & omit a word (-) & 6 & $3,27 \%$ & \\
8. & add a word (+) & 4 & $2,18 \%$ & \\
9. & meaning not clear & 3 & $1,63 \%$ &
\end{tabular}




\begin{tabular}{|c|c|c|c|}
\hline 10. & word form & 1 & $0,54 \%$ \\
\hline 11. & pronoun & 1 & $0,54 \%$ \\
\hline 12. & word order & 0 & $0 \%$ \\
\hline 13. & preposition & 0 & $0 \%$ \\
\hline
\end{tabular}

In Table 3, it is shown that the students have committed 48 errors of run-on sentence of 183 errors or $26,22 \%$. Then, it is followed by verb order with 47 errors or $25,68 \%$, punctuation with 37 errors or $20,21 \%$, capitalization with 22 errors or $12,02 \%$, spelling with 8 errors or $4,37 \%$, singular/plural with 6 errors or 3,27\%, omit a word with 6 errors or $3,27 \%$, add a word with 4 errors or $2,18 \%$, not clear meaning with 3 errors or $1,63 \%$, word form error with 1 error or $0,54 \%$, meanwhile the word order and preposition have no error ( $0 \%)$.

Table 4. Percentage of the Types of Student's Errors in Task 2 with the Topic “Unforgettable Experience”

\begin{tabular}{ccccc}
\hline No. & Types of Error & $\begin{array}{c}\text { The Number of } \\
\text { Error }\end{array}$ & $\begin{array}{c}\text { Percentage of } \\
\text { Error }\end{array}$ & Task Code \\
\hline 1. & verb tense & 59 & $22,18 \%$ & \\
2. & run-on sentence & 49 & $18,42 \%$ & \\
3. & punctuation & 41 & $15,41 \%$ & \\
4. & capitalization & 35 & $13,15 \%$ & \\
5. & spelling & 23 & $8,64 \%$ & \\
6. & add a word (+) & 14 & $5,26 \%$ & UNE T2 \\
7. & pronoun & 10 & $3,75 \%$ & \\
8. & singular/plural & 9 & $3,38 \%$ & \\
9. & omit a word (-) & 9 & $3,38 \%$ & \\
10. & meaning not clear & 9 & $3,38 \%$ & \\
11. & word form & 4 & $1,50 \%$ & \\
12. & preposition & 2 & $0,75 \%$ & \\
13. & word order & 0 & $0 \%$ & \\
\hline
\end{tabular}

Table 4 shows that from 13 types of error committed by the students, verb tense is the most frequent error made by the $10^{\text {th }}$ grade students of SMK N 1 Denpasar. There are 59 verb tense errors of 264 errors or $22,18 \%$. Moreover, it is followed by run-on sentence with 49 errors or $18,42 \%$, punctuation with 41 errors or $15,41 \%$, capitalization with 35 errors or $13,15 \%$, spelling with 23 errors or $8,64 \%$, add a word with 14 errors or $5,26 \%$, pronoun with 10 errors or $3,75 \%$, singular plural with 9 errors or $3,38 \%$, add a word with 9 errors or 3,38\%, not clear meaning with 9 errors or $3,38 \%$, word form with 4 errors or $1,50 \%$, preposition with 2 errors or $0,75 \%$, word order error is $0 \%$.

\section{The Description of Errors Made by the Students}

Based on the findings, there will be a discussion on the types of errors from the most frequent to the lowest frequent errors. Those are explained briefly as follows.

\section{Capitalization}

In English, capitalization is an important letter in writing. There are many rules for using capital letters, such as at the first word in a sentence, pronoun, proper noun, abbreviations and acronyms. The following examples are capitalization errors made by the students.

(1) We arrived at bali. (HD T1 S23 ST6)

(2) the ticket price was only \$20. (UNE T2 S6 ST5)

(3) we arrived at 10 o'clock. (HD T1 S15 ST2)

Based on the finding (1) it can be seen that the word 'bali' is wrong in capitalization use. In fact, the name of the place should be written in capital for the first letter. Meanwhile, in data (2) 
the letter 'the' is not capitalized. The correct sentences are:

(4) We arrived at Bali. (HD T1 S23 ST6)

(5) The ticket price was only \$20. (UNE T2 S6 ST5)

(6) We arrived at 10 o'clock. (HD T1 S15 ST2)

\section{Punctuation}

Punctuation is used to create sense, clarity and stress in sentences. It can be detected when the students inappropriately use a full stop, comma, colon, semicolon, question mark, exclamation mark, quotation mark, hyphen, slash, parentheses, apostrophes, and ellipsis. Here are some examples of when the students experienced punctuation errors.

(7) Finally ( ) we went home. (UNE T1 S9 ST6)

(8) It was a bad experience () (UNE T2 S15 ST4)

(9) They are my best friend (,) their name are Rico, Ari, Andika, and Wahyu. (HD T2 S12 ST6)

In data (7) the student was missing a punctuation, a comma as a stressing symbol in that sentence. It should be a comma (,) after the word 'Finally'. In data (8) the student misses a full stop (.) at the end of the sentence. Moreover, in data (9), the use of punctuation is wrong. It should be a full stop (.) not a comma because those sentences are in different context. The correct sentences are:

10) Finally, we went home. (UNE T1 S9 ST6)

11) It was a bad experience. (UNE T2 S15 ST4)

12) They are my best friend. Their name are Rico, Ari, Andika, and Wahyu. (HD T2 S12 ST6)

\section{Run-on Sentence}

In data (19) the phrase 'she not protect me' was wrong because in the phrase there is no helping verb. Helping verb is a type of verb that has the ability to modify the meaning of a verb. Although, this word has no lexical meaning. A primary auxiliary verb should be put before the word 'not'. The primary auxiliary should be 'did not' because the sentence tells about a past event. Meanwhile, in sentence (20), the word 'try' should
Run-on sentence are two or more sentences come together without any punctuation between them. The punctuation can be a conjunction, comma, full stop or others. The following are some examples.

(13) After 3 hours walking in the dark, we could reach the top of the mountain. (HD T2 S23 ST8)

(14) Although I still feel sick after the incident, I feel happy to be spending time with friends. (HD T1 S26 ST15)

(15) In the morning I went to tamblingan lake camp by car, while trip we felt very happy. (HD T1 S28 ST2)

It can be seen in data (13), (14), and (15), that run on sentence occur because there is no sign or mark between two or more sentences. The target sentences are:

(16) After 3 hours walking in the dark. We could reach the top of the mountain. (HD T2 S23 ST8)

(17) Although, I still feel sick after the incident. I feel happy to be spending time with friends. (HD T1 S26 ST15)

(18) In the morning, I went to Tamblingan lake camp by car. While trip we felt very happy. (HD T1 S28 ST2)

\section{Verb Tense}

Verb tense is a kind of errors in using a verb. Verb error is a verb form in English to show the time (present, past, or future) which shows the occurrence of an action or event. The use of verb tense should follow the grammatical rules. The following examples are:

(19) My mom so angry to my sister because she not protect me. (UNE T2 S16 ST19)

(20) I try to rode a horse without any skill. (HD T1 S10 ST8)

be 'tried' because the sentence is about the experience in the past. Then, the word 'rode' has an incorrect verb form. The word 'to' should be followed by verb 1 because to is infinitive. The correct sentences are:

(21) My mom so angry to my sister because she did not protect me. (UNE T2 S16 ST19)

(22) I tried to ride a horse without any skill. (HD T1 S10 ST8) 


\section{Pronoun}

Pronoun is a word used to replace a noun that can be people, objects, places and animals. It can be replaced by a noun in which it is used to avoid the repetition of the noun. Pronoun error also can be influenced by the placement of the pronoun. The followings are examples of pronoun errors.

(23) Three weeks ago, me and my friend went to the campsite. (HD T1 S16 ST1)

(24) Last year, I and my family went to Lovina Beach. (HD T1 S25 ST1)

(25) Me and my friends took a lot of picture. (UNE T2 S4 ST10)

It can be seen in data (23) and (25) that the pronoun errors of both sentences are based on the placement of pronoun 'me and my friends'. The object ' $m e$ ' is mistaken for the subject pronoun I. In a compound subject or object, the pronoun 'my friends' should be states first. It should be 'my friends and I'. Meanwhile, in data (24), it also has the same reason. The plural noun should be stated first, then followed by the singular noun. So, the error is 'I and my family'. The correct pronoun is 'my family and I'. The correct sentences are:

(26) Three weeks ago, my friends and I went to the campsite. (HD T1 S16 ST1)

(33) Then, the teacher comes to the classroom. (UNE T2 S10 ST13)

(34) It was the most pleasurable place for me. (UNE T2 S13 ST10)

(35) It was an unforgettable experience for me. (UNE T2 S24 ST12)

\section{Add a Word}

Add a word means to perform addition or to make an additional word in a sentence. Add a word is needed in a complete sentence. There is no item of morphemes that must appear in a sentence. Sometimes, students forget to put an item of morphemes that must appear in their sentence. Thus, they make an error in the types of adding a word error. The following are some examples of add a word error.
(27) Last year, my family and I went to Lovina Beach. (HD T1 S25 ST1)

(28) My friends and I took a lot of picture. (UNE T2 S4 ST10)

Spelling

Error that occurs in spelling is an error or students do not know the correct spelling. The fact is in the process of student's recount writing, there are still many students have an error. Spelling errors caused by misspelling and they make the reader misunderstand. Even though, the misspelling is still understandable. But, it is still incorrect. The following examples of spelling errors.

(29) Then, the teacher comes to the classrom. (UNE T2 S10 ST13)

(30) It was the most pleasurerable place for me. (UNE T2 S13 ST10)

(31) It was an unforgetable experience for me. (UNE T2 S24 ST12)

(32) From example, in data (29), it can be seen that the students did an error in a word 'classrom'. In data (30) the students also did an error while writing a word 'pleasurerable'. Data (31) shows that the students did an error in spelling a word "unforgetable. The correct sentence are:

(36) It was so dark and we only used ${ }^{\wedge}$ flashlight to get the way. (HD T2 S26ST5)

(37) I went to ${ }^{\wedge}$ airport. (UNE T2 S6 ST8)

(38) I ran to ${ }^{\wedge}$ bathroom to take a bath. (UNE T2 S18 ST3)

From the example, it can be seen in data (35), (36), and (37) that the students did not put the article 'the'. The article 'the' is used to describe a specific or certain thing. The following are some examples taken from the student's writing recount text.

(39) It was so dark and we only used the flashlight to get the way. (HD T2 S26 ST5)

(40) I went to the airport. (UNE T2 S6 ST8)

(41) I ran to the bathroom to take a bath. (UNE T2 S18 ST3) 


\section{Singular/Plural}

A singular noun is a single noun that consists of only one object. It can be identified by putting article 'a' or 'an' before noun. A plural noun is a noun that consists of more than one object. It can be added by a suffix -s or -es after a noun, which will create a plural form. There can be seen in data (41) to (43).

(42) I fell for many time when I rode a horse. (HD T1 S24 ST9)

(43) We set up a tents to rest at night. (HD T1 S25 ST4)

(44) One years ago, we went to Buyan Lake in the morning. (UNE T2 S5 ST1)

In data (41), it can be seen that before the word 'time' there is a word 'many', it shows that it is a plural noun, so it should be added by a suffix s. In data (42) before a word 'tents' there is an article ' $a$ ', it shows that it is a singular noun. Therefore, the suffix $-s$ should be omitted. Furthermore, in data (43) before the word 'years' there is a number that shows only one object. So, the suffix $-s$ should be omitted. The correct sentences were:

(45) I fell for many times when I rode a horse. (HD T1 S24 ST9)

(46) We set up a tent to rest at night. (HD T1 S25 ST4)

(47) One year ago, we went to Buyan Lake in the morning. (UNE T2 S5 ST1)

\section{Omit a Word}

Omit a word means that there is an unnecessary item occurred in a sentence. So, unneeded item in a sentence must be omitted or removed. Based on the student's writing recount text, students pun an item of a word that is not necessary for their sentence. The following are some example of omitting a word error.

(48) We got ready to clean the beach and took off the tent and went back to home with my friends. (HD T2 S29 ST13)

(49) On the next day, we played near the lake. (HD T1 S22 ST10)

(50) The water is very very cold. (UNE T2 S24 ST8)
From example (47), it can be seen that the student added an unnecessary word 'to'. In data (48) the word 'on' should be omitted. Then, in data (49) the word 'very' should be omitted because he or she translated his or her sentence from Indonesian pattern into English pattern. Therefore, the sentence was translated into a literal translation. The correct sentences are:

(51) We got ready to clean the beach and took off the tent and went back home with my friends. (HD T2 S29 ST13)

(52) The next day, we played near the lake. (HD T1 S22 ST10)

(53) The water is very cold. (UNE T2 S24 ST8)

\section{Preposition}

Preposition is a word which comes together with an object. Based on its function, there are several kinds of preposition namely, preposition of time is used to give time instructions. Preposition of a place is used to indicate a place. The preposition of movement is used to provide direction for movement. The followings are examples of preposition errors.

(54) Last week, in Saturday morning I and family went to Toba Lake camp and Zoo. (HD T1 S21 ST1)

(55) We went home on the evening. (HD T1 S27 ST10)

(56) We decided to go home on $06: 00 \mathrm{pm}$ on that day. (HD T2 S2 ST6)

From example (53) it can be seen that the word 'in' was an error of a preposition. It should be 'on'. It should be used if the following nouns denote a date, a day of the week, or days of celebration. Example (54), shows that the word 'on' was an error of punctuation. It should be 'in' because the following nouns denote a moment of the day. Furthermore, in data (55), it can be seen that the preposition 'on' is an error form. It should be the preposition 'at'. The preposition 'at' is suitable to change the preposition ' $o n$ ' in that sentence because it denotes an hour or specific time. The correct sentences are:

(57) Last week, on Saturday morning I and family went to Toba Lake camp and Zoo. (HD T1 S21 ST1) 
(58) We went home in the evening. (HD T1 S27 ST10)

(59) We decided to go home at 06:00 pm on that day. (HD T2 S2 ST6)

\section{Meaning Not Clear}

Meaning not clear is a sentence that is not interpretable. It is because the students did not care about grammatical rules. The followings are some examples of meaning not clear errors.

(60) After the swam we immediately rushed to went home each. (UNE T2 S3 ST6)

(61) Fell and we helped her luckly my friend was no why why. (UNE T1 S7 ST3)

(62) Tomorrow my family and I took leave to return to Denpasar because there is a parent job. (HD T2 S7 ST10)

It can be seen that the meaning of those sentences cannot be interpreted. It happens because of the literal translation is done without considering about grammatical rules.

\section{Word Form}

Word Form is the process of forming a word or changing the form of a word based on grammatical rules. It can be used to describe something. The following are the examples.

(63) After that we went to tent to prepare our self for packed to home. (HD T1 S20 ST12)

(64) I got the sprain in my left feet and I falled because a hole. (UNE T2 S20 ST6)

(65) Last year, my friends and I attenden a theater competition in SMAN 2 Denpasar. (UNE T2 S17 ST1)

Example (62), shows that there is a phrase 'our self' as a reflexive pronoun. The use of the reflexive pronoun is based on the subject forms of a personal pronoun. It can be seen that the subject is plural, so the word "ourselves" should be used. Moreover, the word 'falled' in data (63) shows an error of pattern. Based on the content of the text the word 'fell' should be used. It is because the sentence tells about an experience in the past. Furthermore, in data (64) the word 'attenden' is an error of pattern. It is because there is no word 'attenden' in English grammar. The sentence tells about the past experience, so the suitable word should be attended. The correct sentences are:
(66) After that we went to tent to prepare ourselves for packed to home. (HD T1 S20 ST12)

(67) I got the sprain in my left feet and I fell because a hole. (UNE T2 S20 ST6)

(68) Last year, my friends and I attended a theater competition in SMAN 2 Denpasar. (UNE T2 S17 ST1)

\section{Word Order}

Word order error is characterized by an incorrect order of syntactic rules of a language. It is the placement of the core element in a sentence. It refers to how different languages can employ different orders. The following examples of word order errors are:

(69) We finally arrived at the lake of Buyan. (HD T1 S1 ST5)

(70) On the Beach Kuta the air is very cool. (HD T2 S2 ST4)

It can be seen in data (68) that the phrase 'the lake of Buyan' should be Buyan Lake. Meanwhile, in example (69), the word 'Beach Kuta' should be replaced by 'Kuta Beach'. The correct sentences are:

(71) We finally arrived at Buyan Lake. (HD T1 S1 ST5)

(72) On the Kuta Beach the air is very cool. (HD T2 S2 ST4)

As what had been mentioned in previously, there were theoretical and empirical reviews used in this study. The researcher has analyzed the types and sources of errors based on the theories mentioned. The findings of this research should be compared to those theories and studied. In order to find out whether this study is in line or contrast to them.

Based on the analysis of types of errors in student's recount writings, it is found that the students still made errors. The researcher has already used some styles in order to instruct the students to write recount text. On the process of delivering the task, the researcher gave them two themes of recount writings, namely; holiday and unforgettable experience. Each theme has two kinds of style in writing such as guided writing and free writing. So, the total of each student writings would be four tests for every student. Based on that test, the most frequent of error is free writing 
theme holiday with the total number of error is 328. The second one is a guided writing theme holiday is 307 errors. In the second meeting, the researcher instructed them to make an unforgettable experience with guided and free writing text. Then, they undergo a drastic change. The total of errors in guided writing is 183 while in free writing is 264 . It can be concluded that the result in the second meeting is better than the first meeting.

The researcher classifies the errors into 13 types of errors, namely: singular/plural, word form, verb tense, add a word, omit a word, word order, spelling, punctuation, capitalization, meaning not clear, run-on sentence, preposition, and pronoun. The most frequent type of errors committed by students were capitalization with 78 errors or $23,70 \%$ of 13 types of errors. In line with (Noviyanti, 2013) finding, the highest percentage of errors is the errors of selection with $57,9 \%$ of the total of errors. In contrast with (Nasrudin, 2015), he found that there are $16,66 \%$ errors of misinformation on students' error in using punctuation mark in narrative writing. Moreover, (Maulita \& Sari, 2015) found some errors on her study of interlingual errors and intralingual errors found in the English narrative text. They found the highest percentage of errors are interlingual errors with $30,26 \%$ of errors.

\section{Sources of Errors}

In this section, the sources of errors in this study will be discussed. Based on (Richards, 1971) and (Brown, 1980), there are four classifications of sources of errors, namely; intralingual error, interlingual error, communication strategy, and context of learning. In order to find the source of errors, the researcher analyzed based on the result of student's writing. The errors were caused by the students namely: intralingual error, interlingual error, and communication strategy as can be seen in Figure 2.

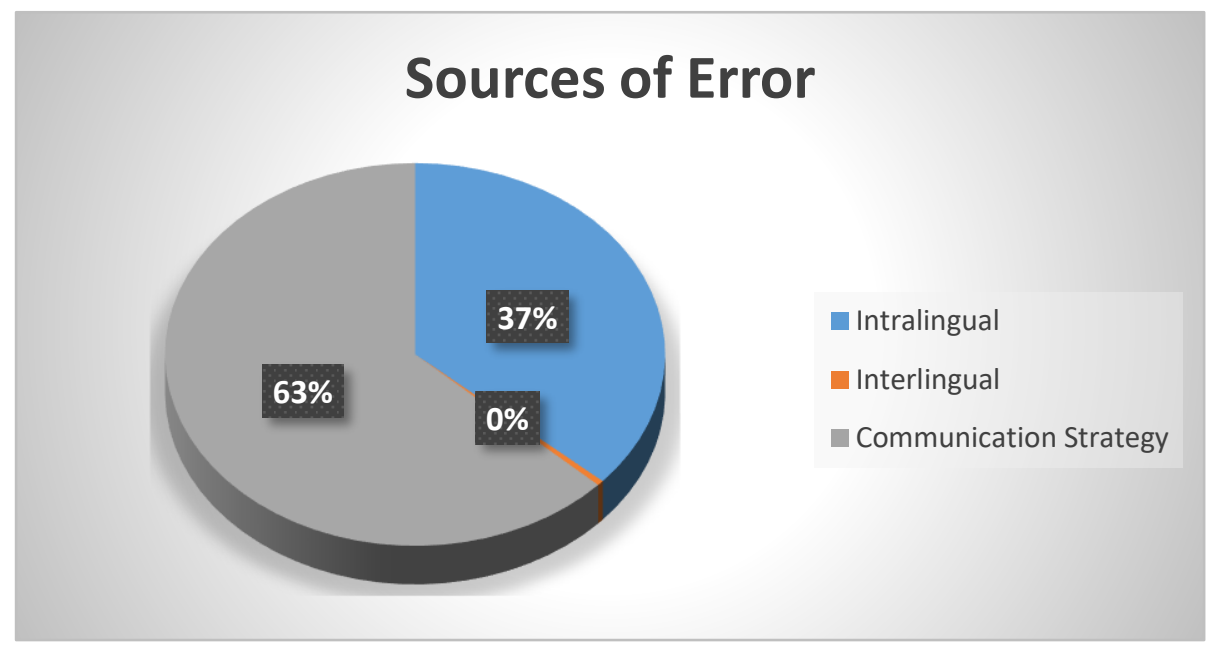

Based on the result of the analysis, it is found that there are three sources of errors, namely; Intralingual, Interlingual and Communication
Strategy. The table 4.5 shows the examples of classification of sources of errors.

Table 5. Classification of Students' Sources of Errors

Error Form Source of Error

a. On Saturday, I and my school are went camping. (HD T1 S10 ST1)

b. And then, we decided to went to our tent and went to slept. (HD T1 S20 ST9)

Intralingual Error

Lingua Scientia | 47 
c. I was decided to go home. (UNE T1 S20 ST5)

d. Finally, we arrived at the lake of Buyan. (HD T1 S1 ST5)

e. Finally, we arrived at the beach kuta, on the

Interlingual Error beach kuta very clean and the air cool. (HD T2 S1 ST4)

f. Finally we went hom on the evening. (HD T1 S4 ST11)

g. Finally () we decided to go home. (HD T2 S10 ST5)

\section{Communication Strategy}

h. that was my embarrassed experience. (UNE T1 S20 ST7)

After analyzing the sources of error, those sources of errors are calculated in order to find out the total number of each error. The recapitulation concerning the sources of errors are put in recapitulation table which can be seen in Appendix V. From the recapitulation, it is found that there are 587 errors caused by communication strategy with the percentage of $63 \%, 340$ errors are caused by intralingual with the percentage of $37 \%$, and 4 errors are caused by interlingual with the percentage of $0,42 \%$. In the following, there will be an explanation about the sources of errors started from the highest to the lowest frequency of errors.

\section{Communication Strategy}

This error occurs based on the student's learning styles. The researcher found that the students just wrote anything they have in their mind. In result, they made errors in the types of spelling, capitalization, or add unnecessary item. The following are the examples of sentence.

(73) Finally we went hom on the evening. (HD T1 S4 ST11)

(74) Finally () we decided to go home. (HD T2 S10 ST5)

(75) that was my embarrassed experience. (UNE T1 S20 ST7)

It can be seen, in data (72), there are some errors in spelling. The word 'hom' should be 'home'. Moreover, in data (73) the students made an error in punctuation. In data (74), the students made an error in capitalization. The first letter should be in capital letter. The correct sentences are:
(76) Finally we went home on the evening. (HD T1 S4 ST11)

(77) Finally, we decided to go home. (HD T2 S10 ST5)

(78) That was my embarrassed experience. (UNE T1 S20 ST7)

Intralingual Error

Intralingual error refers to language items produced by the learner, which was not reflected in the structure of the mother tongue in this case Indonesia. This source of errors can be classified into four categories. Namely; overgeneralization, incomplete application of rules, false concept hypothesized, and ignorance of rule restriction.

(79) On Saturday, I and my school are went camping. (HD T1 S10 ST1)

(80) And then, we decided to went to our tent and went to slept. (HD T1 S20 ST9)

(81) I was decided to go home. (UNE T1 S20 ST5) From example (78), it can be seen that the phrase 'are went' is wrong. The students overgeneralized the rules and the word 'are' should be omitted. Meanwhile, in data (79) it can be seen that the students did an error by ignoring the rule. It is because of the to infinitive cannot be followed by verb 2 . It should be followed by verb 1. From example (80), it is found that a false concept hypothesized occurs because the word 'was' in that sentence is not necessary.

\section{Interlingual Error}

This source occurs because of the interference of Indonesia as their first or native language. The students directly transfer Bahasa 
Indonesia language into English form without considering the grammar rules. The following are some examples of the errors.

(82) Finally, we arrived at the lake of Buyan. (HD T1 S1 ST5)

(83) Finally, we arrived at the beach kuta, on the beach kuta very clean and the air cool. (HD T2 S1 ST4)

From the examples, it can be seen that both sentences in data (81) and (82) Bahasa Indonesia are directly transferred into English. The correct sentences are:

(84) Finally, we arrived at Buyan Lake. (HD T1 S1 ST5)

(85) Finally, we arrived at Kuta Beach, on Kuta Beach very clean and the air cool. (HD T2 S1 ST4)

From the explanation, it can be seen that the sources of errors committed by the students are mostly caused by intralingual errors. It is followed by interlingual errors and communication strategy.

\section{CONCLUSION AND SUGGESTION}

This section deals with the conclusion and some suggestions for teachers, students, and other researchers.

\section{Conclusion}

Based on the findings and discussion, the result of the analysis shows that the $10^{\text {th }}$ grade students of SMK Negeri 1 Denpasar performed 13 types of errors . Capitalization is the most frequent errors in which the students committed 78 errors of 328 errors in theme holiday task 2 . If it is sorted by theme, on HD T1 theme, the most number of errors are punctuation with 73 errors or $23,77 \%$, capitalization with 51 errors or $16,61 \%$, run-on sentence with 45 errors or $14,65 \%$, verb tense with 37 errors or $12,05 \%$, pronoun with 25 errors or $8,14 \%$, spelling with 18 errors or $5,86 \%$, omit a word with 15 errors or $4,88 \%$, preposition with 11 errors or $3,58 \%$, singular/plural with 8 errors or $2,60 \%$, add a word with 7 errors or $2,28 \%$, meaning not clear with 7 errors or $2,28 \%$, word form with 5 errors or $1,62 \%$, and word order with 3 errors or $0,97 \%$. Next, in HD T2, the result shows that the order of errors are capitalization with 78 errors or $23,70 \%$, run-on sentence with 65 errors or $19,75 \%$, punctuation with 55 errors or $16,71 \%$, verb tense with 39 errors or $11,85 \%$, add a word with 18 errors or $5,47 \%$, pronoun with 18 errors or $5,47 \%$, singular/plural with 16 errors or $4,86 \%$, spelling with 15 errors or $4,55 \%$, omit a word with 11 errors or 3,34\%, meaning not clear with 6 errors or $1,82 \%$, preposition with 3 errors or $0,91 \%$, word form with 2 errors or $0,60 \%$, and word order with 2 errors or $0,60 \%$. In UNE T1, the errors orders are run-on sentence with 48 errors or $26,22 \%$, verb tense with 47 errors or $25,68 \%$, punctuation with 37 errors or $20,21 \%$, capitalization with 22 errors or $12,02 \%$, spelling with 8 errors or $4,37 \%$, singular/plural with 6 errors or $3,27 \%$, omit a word with 6 errors or $3,27 \%$, meaning not clear with 3 errors or $1,63 \%$, word form with 1 error or $0,54 \%$, pronoun with 1 error or $0,54 \%$, and there is no error for word order and preposition. Finally, in UNE T2, the errors made by students are verb tenses with 59 errors or $22,18 \%$, run-on sentence with 49 errors or $18,42 \%$, punctuation with 41 errors or $15,41 \%$, capitalization with 35 errors or $13,15 \%$, spelling with 23 errors or $8,64 \%$, add a word with 14 errors or $5,26 \%$, pronoun with 10 errors or $3,75 \%$, singular/plural with 9 errors or $3,38 \%$, omit a word and meaning not clear has the same numbers of errors with 9 errors or 3,38\%, word form with 4 errors or $1,50 \%$, preposition, and no error in word order. Based on the result of students' recount writing texts, there are three types of source of errors that lead the students to make errors in writing recount texts. Those are intralingual, interlingual, and communication strategy. It can be concluded that the most frequent errors are caused by the communication strategy with 587 errors or $63 \%$, intralingual with 336 errors or $36,51 \%$, and interlingual with 4 errors or $0,42 \%$.

\section{Suggestions}

By analyzing the result of this study, there are some suggestions given as the contribution of this study to teachers, students, and other researchers. The teachers should be aware of the errors faced by the students. The teacher should emphasize more on the errors made by students. Thus, the teacher could teach them more effectively. Teachers should change the strategy in 
writing recount text. Teachers can use guided writing in order to avoid errors. Based on the result of this study, the researcher found that the result of guided writing has less error rather than free writing. Therefore, this strategy is better to be applied. The students must be aware about English grammar. It is because English grammar has many different forms from the structure in Bahasa Indonesia. Other researchers can use the result of this study as a reference in conducting similar studies.

\section{REFERENCES}

Afifuddin, A. (2016). An analysis of students' errors in writing descriptive texts. English Education Journal, 7(1), 130-139.

Anderson, K. (2010). Text types in English. Australia: Macmillan.

Anderson, M. and K. A. (1997). Text types in English 1. Malaysia: Macmillan.

Artana, D. (2012). An analysis of grammatical errors cpmmotted by class VII A6 students of SMPN 1 Singaraja in writing descriptive paragraph in the academic year of 2011/2012. Unpublished Thesis Undiksha.

Azar, B. S. (1999). Understanding and using english grammar (Third Edit). New York: Pearson Education.

Barwick, J. (1999). Targeting text: Photocopiable units based on English text types, upper level. Glebe: Blake Education.

Biber, D. (1991). Variation across speech and writing. Cambridge University Press.

Boice, R. (1993). Writing blocks and tacit knowledge. Journal of Higher Education, 6(1), 19-53.

Brown, H. . (1980). Principle of language learning and teaching (Fifth Edition). USA: Longman.

Brown H, D. (1980). Principles of language learning and teaching. New Jersey: Prentice Hall Inc.

Corder, S. . (1977). Introducing applied linguistics. New York: Penguin Books.
Corder, S. P. (1981). Error analysis and interlanguage. New York: Oxford University Press.

Dulay, H., Burt, M., Krashen, S. (1982). Language two. Walton Street: Oxford University Press.

Elbow, P. (1973). Writing withoutteachers. Oxford University Press.

Ellis, R. (1997). Second language acquisition. Oxford University Press.

Fatmawati, I. (2016). Grammatical errors in descriptive text made by eighth graders of olympiad and bilingual students.

Harmer, J. (2001). The practice of English language teaching (Third edition). Landon: Logman.

Harmer, J. (2004). How to teach writing. Malaysia: Longman.

Hartati, S. Y. (2017). Analisis kesalahan penggunaan kalimat efektif dalam artikel ilmiah mahasiswa program studi Pendidikan Bahasa dan Sastra Indonesia STKIP PGRI Sumatera Barat. Unika Atma Jaya.

Holdich, C. E., \& Chung, P. W. H. (2003). A "computer tutor" to assist children develop their narrative writing skills: Conferencing With HARRY. International Journal of HumanComputer Studies, 59(5), 631-669.

Hyland, K. (2004). Genre and second language writing. London: The Univercity of Michigan Press.

Jannah, K. (2013). Using collaborative writing technique through mixendinks as media in teaching writing a discussion text at senior high school. Journal of English Language Teaching, 2.

Maulita, E., \& Sari, P. (2015). Interlingual errors and intralingual errors found in narrative text written by efl students in Lampung, (1), 8795.

Meyers, A. (2005). Gateways to academic writing: Effective sentences paragraph and essay. New York: Longman. 
Nasrudin, H. (2015). The students ' error in using punctuation marks Department of English Education Faculty of Tarbiya and teachers ' training Syarif Hidayatullah State Islamic University $2015 \mathrm{M}$ the student 's error in using punctuation mark in narrative writing department.

Nation, P. (2009). Teaching and learning writing. Cambridge University Press.

Noviani, A. (2015). An error analysis on students' recount writing (A case study at second grade students of SMP Mutiara Harapan Pondok Aren).

Novita, R. (2014). An analysis of grammatical errors in the 1st year students' writings at English Department, Andalas University. Vivid Journal, 3(2), 1-15. https://doi.org/http://dx.doi.org/10.23971/je fl.v5i2.368

Noviyanti, S. (2013). An analysis on students' grammatical errors in writing descriptive paragraph (A case study at the second grade Of Smpn 3 Tangerang Selatan).

R, L. (1957). Linguistics across cultures. Ann Arbor, MI: University of Michigan Press.

Reynolds, M. (1988). Make free writing more productive. College Composition and Communication.

Richards, J. . (1971). A non- contrastive approach to error analysis. Journal of ELT, 25, 204-219.

Selinker, L. (1972). The interlanguage hypothesis (pp. 209-231). IRAL 10.

Silva, T. (1990). Second language composition instruction; Development, issues, and direction in ESL. New York: Cambridge University Press.

Troyka, L. (1987). Defining basic writing in context. New York: Random House.

Tyner, B. (2004). Beginning reading instruction and the small-group differentiated reading model. International Reading Association.
Zawahreh, F. A. S. (2012). Applied error analysis of written production of english of tenth grade students in Ajloun Schools, Jordan. International Journal of Learning \& Development, 2, 281-287. 
